\section{Fjernundervisning av point-of-care (POC) ultralyd}

SAFER (Stavanger Acute medicine Foundation for Education and Research) startet i 2014 et eget utdanningsprogram for ultralyd kalt SAFERSOUND. Det ble etter hvert utviklet et konsept kalt UltraBox med formål om å tilby fjernundervisning til læresteder utenfor Stavanger og Norge. Første kurs ble avholdt januar 2015 og kursdeltagerene var medisinstudenter ved distriktsuniversitetet Szczecin i Polen. Hovedtemaet for kurset var ,point-of-care ultralyd“. I forkant av kurset fikk arrangørene tilsendt en transportkasse med alt nødvendig utstyr, blant annet ultralydmaskiner, simulatorer og webkamera samt datautstyr. Arrangøren måtte selv stille med kurslokale samt ordne med det administrative. Alle påmeldte studenter

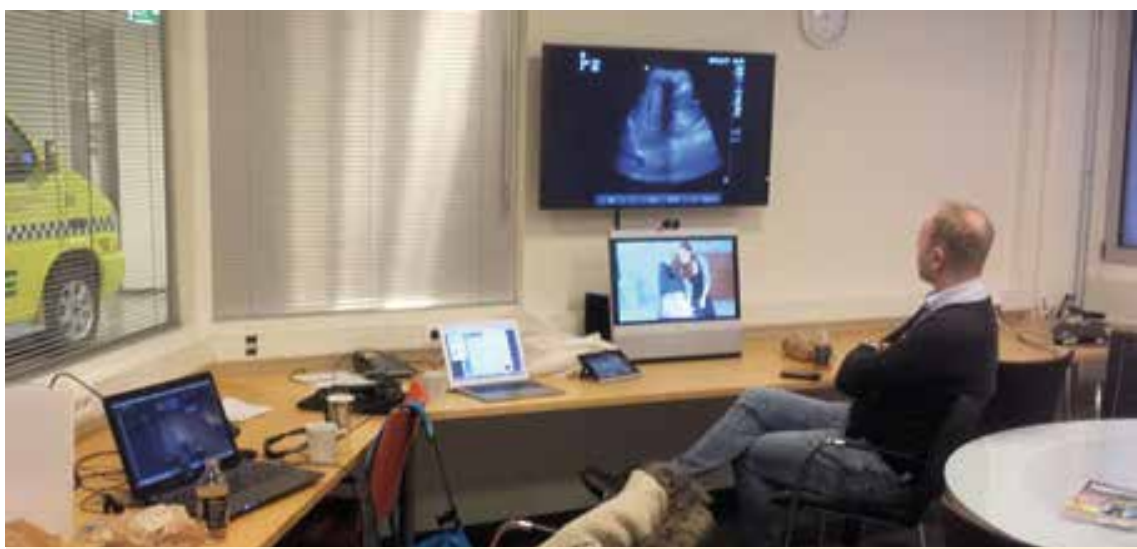

Spesialist i Point-of-Care ultralyd, anestesilege Nils Petter Oveland, overvåker en skannestasjon fra SAFER sine lokaler i Stavanger.

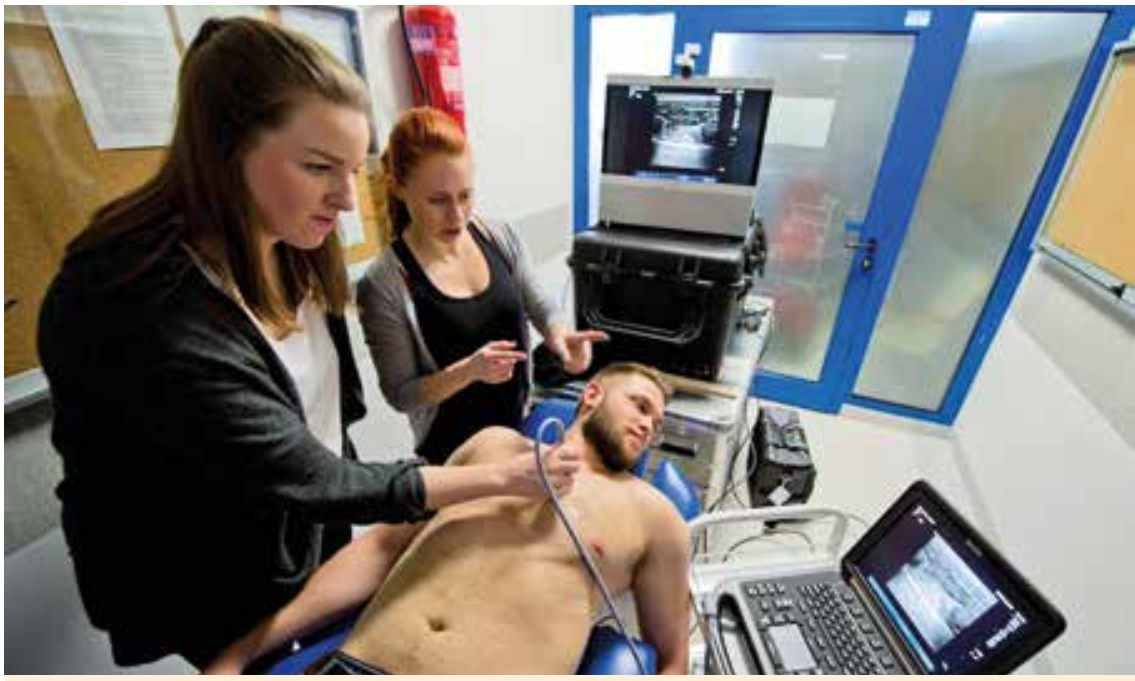

Skannestasjon i Polen. Et webkamera overfører live-bilder til Stavanger. måtte i forkant av kurset gjennomgå et elæringsprogram og ta en test for å sikre nødvendig forkunnskap.

Kursdagen startet med forelesning i ultralydfysikk og maskinlære. Forelesningen ble gitt i form av PowerPoint presentasjon av sonograf Victoria Vatsvåg ved hjelp av videokonferanse. Det var fem lokale instruktører tilstede i Polen, alle medisinstudenter med utdanning i ultralyd. Instruktørene ga korte oppsummeringsforelesninger i forkant av hvert tema innen POC ultralyd. Hoveddelen av kurset var satt av til hands-on trening der studentene scannet hverandre og på simulatorer. Disse hands-on sesjonene ble overvåket av spesialist innen POC ultralyd, anestesilege Nils Petter Oveland og sonograf Victoria Vatsvåg fra SAFER sine lokaler i Stavanger. De hadde tilgang til liveoverføring av ultralydbildet på maskinen og av skanneobjektet og studenten. Dette ga et svært bra grunnlag for å veilede studenten i både skanneteknikk og bildeoptimalisering.

Det var også stor hjelp i å ha lokale instruktører til stede. De eksterne underviserne hadde mulighet til å bruke „pointer“ på ultralydbildet og dette fungerte svært bra, det nest beste etter å være fysisk til stede og peke på skjermen. De eksterne underviserne hadde i forkant av kurset laget et bildebibliotek med relevant anatomi og patologi som ble flittig brukt, da det ikke var „ekte“ pasienter som ble skannet og derfor (heldigvis) heller ingen patologi å finne.

Tilbakemeldingene etter kurset har vært svært gode og det planlegges nå flere kurs, i første omgang for norske medisinstudenter ved universiteter i Mellom-Europa. 